\title{
BCR/ABL1 Fusion Protein p210
}

National Cancer Institute

\section{Source}

National Cancer Institute. BCR/ABL1 Fusion Protein p210. NCI Thesaurus. Code C99309.

A fusion protein encoded by the BCR/ABL1 fusion gene. This protein is comprised of the first 902 or 927 amino acids from the $\mathrm{N}$-terminus of the breakpoint cluster region protein fused to almost the entire tyrosine-protein kinase ABL1 protein. 